\title{
Cardiac masses - differential diagnosis: metastatic melanoma of the right ventricle mistaken for a thrombus
}

\section{Sandra Makarović* \\ Zorin Makarović \\ Ranko Ugljen \\ Kristina Selthofer- \\ Relatić \\ Grgur Dulić \\ Igor Lekšan \\ Jasmina Rajc}

Josip Juraj Strossmayer University of Osijek School of Medicine, University Hospital Centre Osijek, Osijek, Croatia
RECEIVED:

April 13, 2015

ACCEPTED:

April 20, 2015

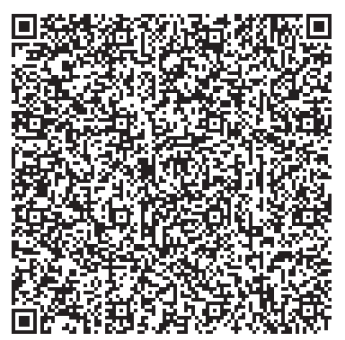

KEYWORDS: cardiac masses, malignant melanoma, cardiac tumor, trombus, right ventricle, cardiac surgery. CITATION: Cardiol Croat. 2015;10(3-4):79. | DOI: http://dx.doi.org/10.15836/ccar.2015.79

ORCID: Sandra Makarović, http://orcid.org/0000-0002-7487-1189 • Zorin Makarović, http://orcid.org/0000-0002-6689-3177 • Ranko Ugljen, http://orcid.org/0000-0002-5832-023X • Kristina Selthofer-Relatić, http://orcid.org/0000-0002-9890-6489 • Igor Lekšan, http://orcid.org/0000-0003-0212-5969 • Grgur Dulić, http://orcid.org/0000-0003-2295-3913• Jasmina Rajc, http://orcid.org/0000-0003-4007-8390

*ADDRESS FOR CORRESPONDENCE: Sandra Makarović, Klinički bolnički centar Osijek, Josipa Huttlera 4, HR-31000, Osijek, Croatia. Phone: +385-91-591-6875. E-mail: sandramakarovic@yahoo.com

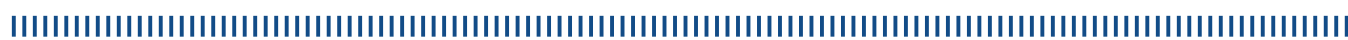

There are three basic types of cardiac masses: tumor, thrombus and vegetation. A differential diagnosis for the echocardiographic finding is based on the location, appearance, size, mobility and physiologic effects of the mass. Other echocardiographic findings such as valvular heart diseases and cardiomyopathies may suggest the mass is a thrombus. Concerning cardiac tumors, nonprimary cardiac tumors are approximately 20 times more common then primary cardiac tumors. The goal of echocardiography in patients with cardiac tumor are: to define the location and extent of tumor involvement; to evaluate obstruction or regurgitation caused by the tumor; to evaluate any associated pericardial effusion and signs of tamponade.,1,2

We present a 53-years-old women presented at Emergency Department in January 2015 with the simptoms of shorteness of breath. Her medical history revealed anamnesis of malignant melanoma on the left femoral region. The patient underwent wide local excision in 1995. Distant metastasis-searching procedures were negative.

In September and October 2014 she was treated from recurrent deep vein thrombosis of left femoral vein. In November 2014 CT angiography was performed, and showed an embolus of left pulmonary artery and a thrombus in the right ventricule. She was treated with therapeutic dose of low molecular heparin.

When she was administrated to Cardiology from the Emergency Department the transthoracic echocardiography were performed and showed large mass in the right ventricle as well in the main pulmonary brunch, obstructing flow in right ventricular outflow tract, compromising cardiac and pulmonary flow.

She was transferred to the Department of Cardiac Surgery immediately, and an operation of the mass in right ventricle was performed. After surgery, all cardiac chambers appeared normal in size and function with associated moderate tricuspid regurgitatin. She was transmitted to oncological treatment. A PHD analysis of the mass showed a malignant melanoma. 